Available online at

www.macvetrev.mk

Original Scientific Article

\title{
POSTURAL BEHAVIOUR IN GILTS HOUSED ON CONCRETE AND RUBBER SLATS DURING FOUR SEASONS
}

\author{
Željko Pavičićc ${ }^{1}$, Mario Ostović ${ }^{1}$, Sven Menčik ${ }^{2}$, Anamaria Ekert Kabalin ${ }^{2}$, \\ Marija Vučemilo ${ }^{1}$, Kristina Matković ${ }^{1}$, Boris Antunović ${ }^{3}$, Rajko Pavešić ${ }^{4}$, Vlatko Ilieski ${ }^{5}$ \\ ${ }^{1}$ Department of Animal Hygiene, Behaviour and Welfare, Faculty of Veterinary Medicine, \\ University of Zagreb, Zagreb, Croatia \\ ${ }^{2}$ Department of Animal Husbandry, Faculty of Veterinary Medicine, \\ University of Zagreb, Zagreb, Croatia \\ ${ }^{3}$ Department of Animal Husbandry, Faculty of Agriculture, Josip Juraj Strossmayer \\ University, Osijek, Croatia \\ ${ }^{4}$ Pavešić Veterinary Clinic, Krasica, Croatia \\ ${ }_{5}^{5}$ Animal Welfare Center, Faculty of Veterinary Medicine, Skopje, Macedonia
}

Received 5 May 2014; Received in revised form 22 July 2014; Accepted 2 August 2014

\begin{abstract}
In the present study, postural behaviour was compared between gilts kept in service unit with different types of flooring during all seasons. The study included four 28-day production cycles and 10 gilts per cycle, equally divided into a control and an experimental group. Control gilts were housed in gestation stalls with slatted concrete floor, whereas in the experimental group the floor was covered with an adjusted rubber mat. Postural behaviour of gilts was observed 4 times per cycle for 4 hours. Study results showed that during cooler seasons, gilts in concrete stalls spent more time standing and lying sternally, whereas gilts in matted stalls were mostly lying, predominantly laterally $(P<0.001$ all). There were no significant between group differences according to the time the gilts spent sitting or the frequency of changing posture in any season observed. Nevertheless, experimental animals spent significantly less time changing standing to both lying positions during all seasons $(P<0.01$ all). In conclusion, rubber mats may improve lying comfort in gilts; however, when using rubber mats, the house thermal conditions should be taken in consideration.
\end{abstract}

Key words: gilts, rubber mats, postural behaviour, welfare

\section{INTRODUCTION}

Historically, pigs were traditionally kept in small to medium herds, in simple housings with straw mostly used as litter for providing comfort and warmth. Over time, pig keeping has been restricted to closed housings with a large number of animals, aiming at increasing the productivity and reducing the cost of pig breeding. This type of pig accommodation required flooring changes. The use of slatted and semi-slatted flooring that requires

Corresponding author: Mario Ostović, $\mathrm{PhD}$

E-mail address: mostovic@vef.hr

Present address: Department of Animal Hygiene, Behaviour and Welfare,

Faculty of Veterinary Medicine, University of Zagreb,

Heinzelova 55, HR-10000 Zagreb, Croatia

Phone: +38512390 294, Fax: +38512441390

Copyright: (C) 2014 Ostović M. This is an open-access article published under the terms of the Creative Commons Attribution License which permits unrestricted use, distribution, and reproduction in any medium, provided the original author and source are credited.

Competing Interests: The authors have declared that no competing interests exist.

Available Online First: 13 August 2014

http://dx.doi.org/10.14432/j.macvetrev.2014.08.020 no litter has become an imperative in pig breeding. However, the new production systems have been found to compromise animal welfare (1).

When kept on slatted and semi-slatted flooring, pigs cannot express their species specific behaviours such as routing or nest building. In addition, pigs prefer lying on solid rather than slatted floor, since the former is warmer (2). As reported by Huynh et al. (3), surface temperature of slatted floor is generally lower by $3-5^{\circ} \mathrm{C}$ as compared with solid floor. Even more so, the housing air quality is lower with slatted flooring (4).

With regards to the type of material, concrete is usually used in flooring construction in animal housing $(5,6)$. Concrete is a durable and relatively inexpensive material, acceptable for maintaining hygiene in these housings. However, the hard, rough and slippery concrete flooring has adverse effects on animal welfare (7). Another disadvantage of concrete flooring in comparison with straw bedding is that it considerably increases the lower 
critical temperature (8). Therefore, the possibilities of improving concrete floor conditions in pig breeding housing have been investigated, with due consideration of their ecologically acceptable properties. One of these attempts implies the use of rubber mats, whereby previous studies have mostly been focused on the injuries and behaviours of lactating and group-housed pregnant sows (9-17).

Flooring comfort is very important in intensive pig breeding because pigs spend up to $80 \%$ of time lying (1) when $8 \%$ to $20 \%$ of the pig body is in contact with the flooring (18). It is even more important when pigs are kept on a relatively small surface (19), as in the case of individual accommodation of pregnant sows.

In the present study, the effect of rubber mats on the welfare of individually kept gilts in a service unit was assessed by observing their postural behaviours.

\section{MATERIALS AND METHODS}

The study was carried out at a pig farm service unit in all seasons of the year during four production cycles, according to the availability of gilts, as follows: May-June (spring), September (summer), November (autumn) and December-January (winter). Each cycle took 28 days. According to the Council Directive 2008/120/EC (20), during this period, breeding females in pig production are usually kept individually in a service unit postmating.

The study included 40 Large White gilts, 10 animals per cycle, randomly divided into two equal groups, a control and an experimental group. Control gilts were kept in usual production conditions, i.e. in gestation stalls (L $1.80 \mathrm{~m} \mathrm{x} \mathrm{W} 0.60 \mathrm{~m}$ ) with slatted concrete floor (slat width $80 \mathrm{~mm}$, gap width 20 $\mathrm{mm}$ ). The concrete floor was in good repair, with no signs of degradation. Experimental animals were kept in identical conditions except for the stall floor being coated with 2-cm adjusted rubber mat of a plug-like pattern (Gumiimpex-GRP Inc., Croatia). Although the rubber mat was not formally tested for comfort properties, its texture appeared softer and less abradant than the concrete floor in the service unit. Rubber mats were connected using the puzzle pattern and attached to the concrete floor. Upon completion of a study cycle, the mats were disconnected, sanitized, and then fitted again before the next cycle.

For about a week before transfer to the service unit, gilts were group-housed in the area intended for sows after weaning, where they had been transported from the group-housed breeding facility for gilts situated on the farm, but separated from other housing. Gilts were transferred from the breeding facility at the age of 6-8 months, when their 158 body mass was around $100 \mathrm{~kg}$. Synchronization of oestrus was previously performed (PG 600 hormone agent, Intervet, The Netherlands) for all gilts to be accommodated in the service unit simultaneously during each cycle observed. Upon synchronization, gilts underwent fertilization on day 5 in the afternoon and then again on day 6 in the morning, to be accommodated in the service unit on day 7 in the morning. As the study gilts were included in the farm technology and production organization, gravidity was diagnosed as usual, during the $4^{\text {th }}$ week of the production cycle in the service unit.

In the service unit, gilts are fed concentrated feed twice a day (7.30 AM and 13.00 PM) with water supply ad libitum. The housing has natural and artificial illumination (for at least $8 \mathrm{~h}$ /day) and forced ventilation. During the cold season, no heating is provided, but acceptable microclimate conditions are achieved by reduced ventilation.

The time the gilts spent in different positions (min), the frequency (n) and duration (sec) of body posture changes were recorded on days 1, 8, 15 and 28 of each cycle. Gilt behaviour was recorded by two digital video cameras (Toshiba Camileo P30, China), fixed on a support, each camera covering one group of gilts. As the study was performed on a commercial pig farm, recording was limited to 4 hours (from 8.30 AM to $12.30 \mathrm{PM}$ ). Upon completion, video recordings were examined and the ethogram was developed including the following postures: standing, sitting, lying laterally and lying sternally.

During the study period, air temperature in the service unit was measured using the portable Testo digital device (Testo Inc., Germany).

Licensed STATISTICA 6.1 software (StatSoft Inc., 1983-2003) was used on statistical data processing and analysis. Distribution of the parameters of posture duration, number and length of posture changes was tested by the distribution fitting test, which yielded normal distribution. The impact of study factors (group, cycle and day) and their interactions on all study parameters (dependent variables) and between-group differences in each parameter during particular cycles were tested by the Generalized Linear Model - Factorial ANOVA. Correlation of air temperature in the service unit with posture duration and number of posture changes was tested by regression analysis.

\section{RESULTS}

The provision of rubber mats very strongly affected the body postures of the gilts in the autumn and winter periods. The lower the air temperature in the service unit (Figure 4), the more time did the 
Postural behaviour in gilts housed on concrete and rubber slats

experimental gilts spend lying in total and lying laterally $(P<0.001$ both) (Table 1$)$.

Table 1. Correlation of service unit air temperature with the length of time the gilts spent in particular postures and posture changes in the control (concrete stalls) and the experimental groups (matted stalls)

\begin{tabular}{|c|c|}
\hline $\begin{array}{c}\text { Control } \\
\text { Experimental }\end{array}$ & Temperature $\left({ }^{\circ} \mathbf{C}\right)$ \\
\hline Standing (min) & $-0.552^{*}$ \\
& $0.396^{*}$ \\
\hline Sitting (min) & 0.142 \\
& 0.167 \\
\hline \multirow{2}{*}{ Lying in total (min) } & $0.541^{*}$ \\
\hline Lying laterally (min) & $-0.480^{*}$ \\
\hline Lying sternally & $0.607^{*}$ \\
(min) & $-0.437^{*}$ \\
\hline \multirow{2}{*}{ Posture change (n) } & -0.107 \\
& -0.023 \\
\hline
\end{tabular}

$* P<0.001, * * P<0.01$
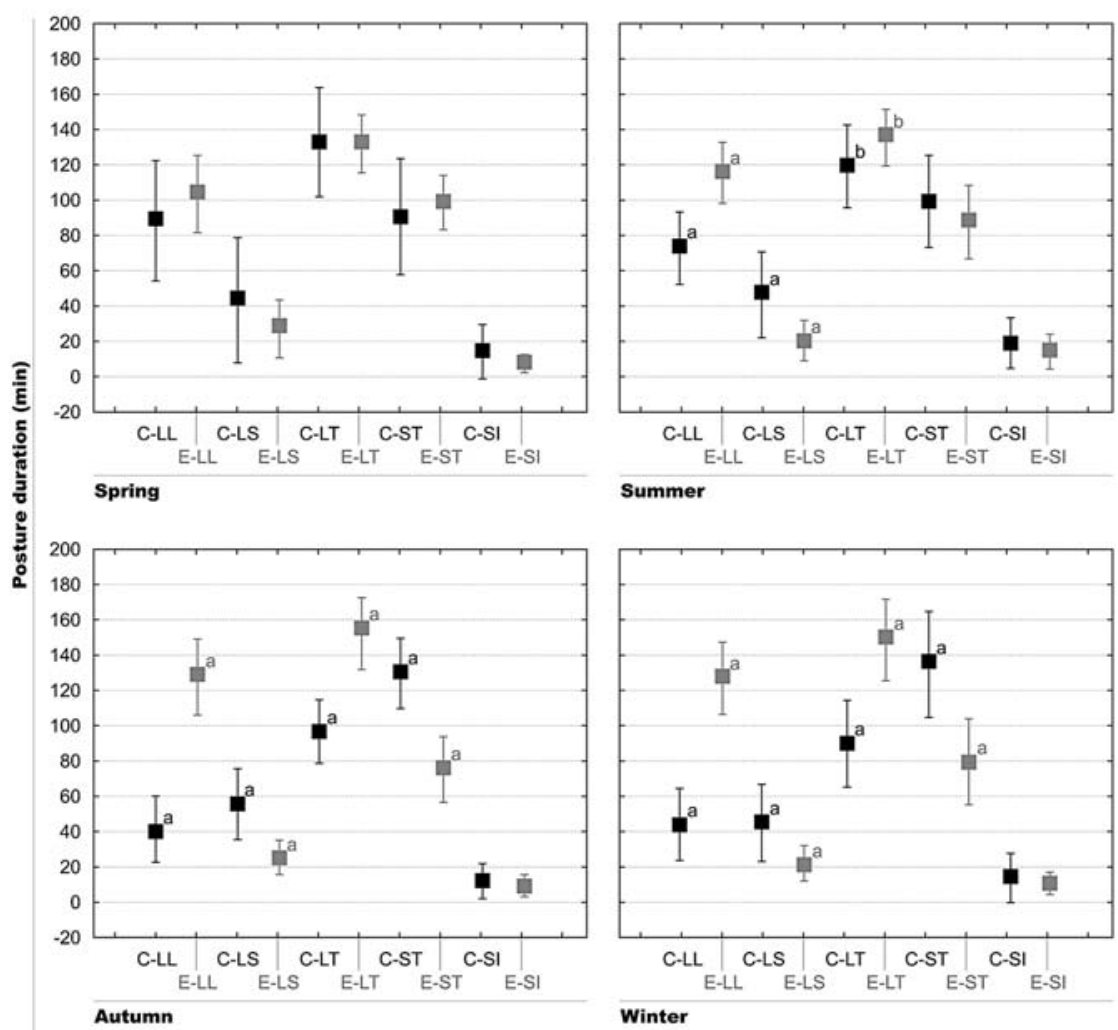

$\square$ Mean I MeantSD

Figure 1. Time spent in different postures in control (concrete stalls) and experimental (matted stalls) group of gilts during a 4-hour period of observation in 4 different production cycles (seasons)

C-control group, E-experimental group, LL-lying laterally, LS-lying sternally, LT-lying in total, ST-standing, SI-sitting, $\mathrm{n}=4$ recordings per season, $\mathrm{n}=5$ gilts per group and season

${ }^{a}$ The same postures during the same season differed statistically significantly between the two groups at the level of $P<0.001$

${ }^{\mathrm{b}}$ The same postures during the same season differed statistically significantly between the two groups at the level $P<0.05$ 
during the summer period. There was no betweengroup difference in the time spent standing in summer (Figure 1). In the spring period, there was no between-group difference in any body posture (Figure 1).

Of all the postures recorded, both experimental and control gilts spent least time sitting. There was no between-group difference according to the duration of sitting in any of the production cycles observed (Figure 1).

The lower the air temperature in the service unit (Figure 4), the less frequent did both control $(P<0.001)$ and experimental $(P<0.01)$ gilts change their body posture (Table 1$)$. However, there was no between-group difference in the number of body postures in any of the production cycles observed (Figure 2).

Considering the speed of posture changes, the analysis included only those posture changes for which an adequate amount of data was available. As illustrated in Figure 3, in all seasons the experimental animals used to change faster standing posture to lying laterally $(P<0.001$ all $)$ and lying sternally $(P<0.001$ all except for $P<0.01$ in the spring production cycle). Concerning other posture changes analysed, lying laterally to standing and sitting, and sitting to standing, there was no significant between-group difference in any season, with the exception of autumn, when experimental gilts spent significantly less time changing their posture from sitting to standing posture $(P<0.01)$.

\section{DISCUSSION}

In modern production, pigs are kept in bare ambient conditions threatening animal welfare. Therefore, ever more attention has been paid to alternative systems of accommodation $(21,22)$. In the present study, concrete flooring for individually housed gilts was covered with rubber mats.

Tuyttens et al. (13) and Elmore et al. (14) report that sows preferred to lie on mats during the cold season, i.e. lying laterally, which could be ascribed to the rubber flooring temperature higher by $1.2-6.7^{\circ} \mathrm{C}$ than the concrete floor temperature (13). Results of our study confirm their finding. The total time the

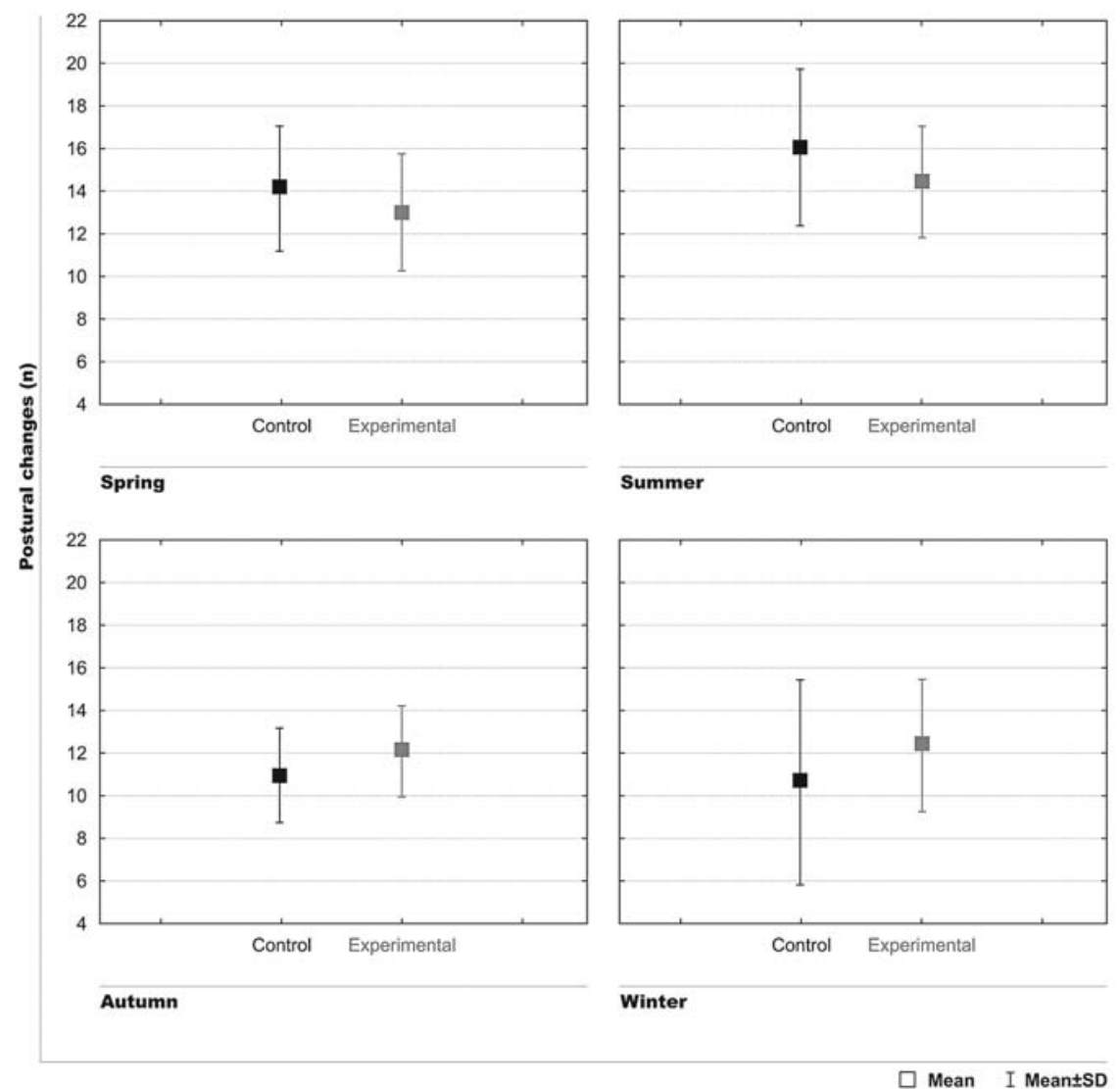

Figure 2. Frequency of posture changing in control (concrete stalls) and experimental (matted stalls) group of gilts during a 4-hour period of observation in 4 different production cycles (seasons) $\mathrm{n}=4$ recordings per season, $\mathrm{n}=5$ gilts per group and season 
gilts spent lying was by about 1 hour longer per 4 hours of observation on rubber mats in autumn and winter (Figure 1). If the 4-hour period is extrapolated to 24-hour period, then the gilts on rubber mats will spend 5-6 hours more lying and 5-6 hours less standing daily. The duration of lying laterally was tripled by the provision of mats during cooler autumn and winter seasons (Figure 1). Therefore, the results indicate that thermal and resting comfort of stall housed gilts is dramatically improved by the provision of rubber mats when housing temperature drops below $18^{\circ} \mathrm{C}$ (Figure 4$)$.

The lower the air temperature (Figure 4), the more time did experimental gilts spend lying laterally, as the predominant form of resting behaviour in pigs (23), whereas control gilts spent more time standing, and vice versa (Table 1). Although air temperature continuously increased during spring and declined during summer, its values were higher in these seasons as compared with autumn and winter (Figure 4) and the gilts housed in matted stalls spent more time lying laterally in these warmer seasons, however, with a weaker or no detectable effect (Figure 1). This finding could suggest that they felt more comfortable on rubber mats irrespective of air temperature, or that it was too warm, since pigs are known to lie laterally when they are warm because this position enables higher heat output to the environment $(24,25)$. However, as the rate of lying sternally was halved in gilts housed on rubber slats in all seasons, i.e. higher in control gilts (Figure 1), while no significant correlation was found between the time spent in sternal position and air temperature in either experimental or control group of gilts (Table 1), differences in lying behaviour were probably due to not only thermal properties, but also to other properties of the mats such as softness.

Pigs often assume sitting position when changing from lying to standing position and vice versa, but they do not spend much time in sitting position (26), as also confirmed in the present study (Figure 1).
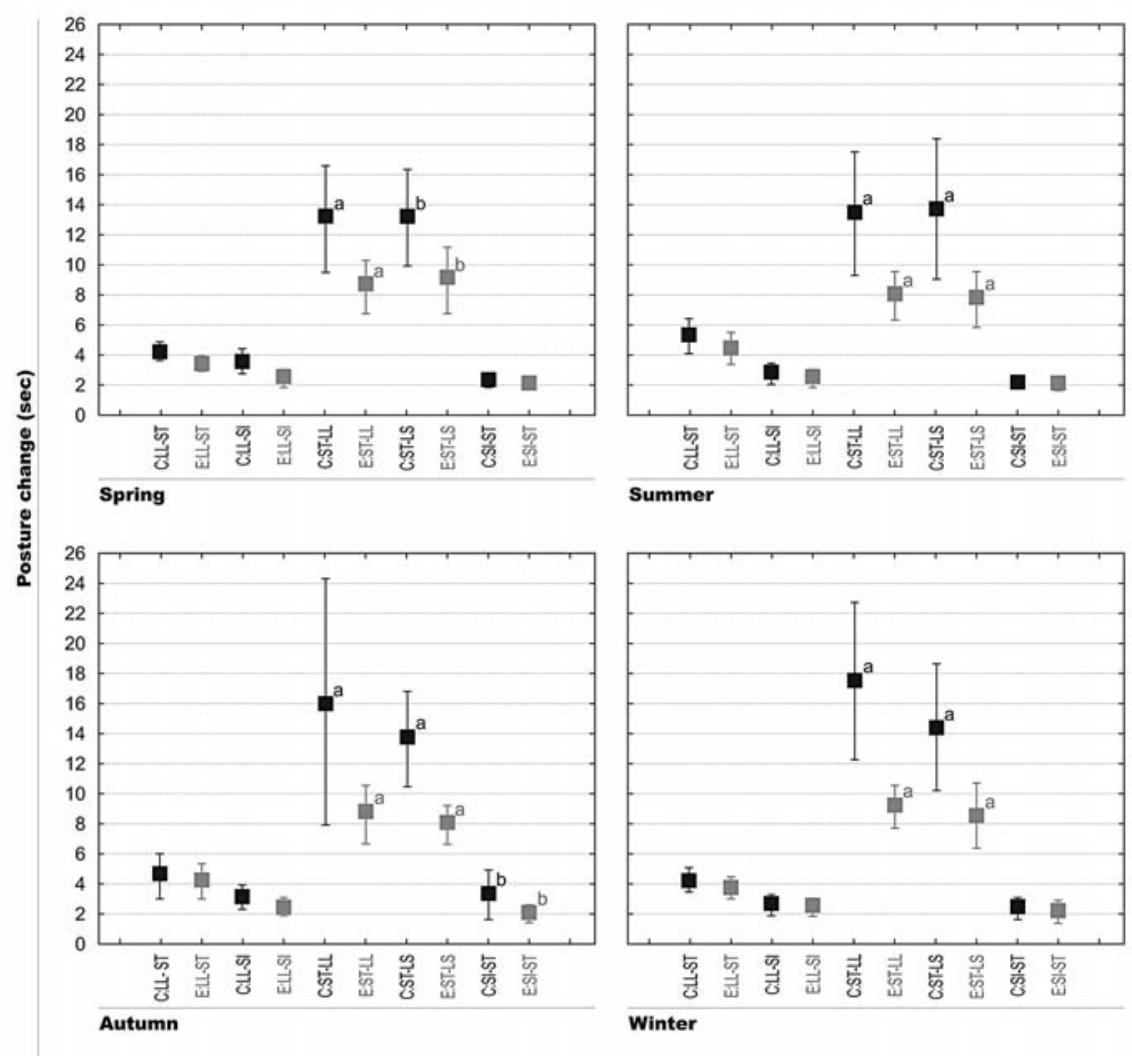

$\square$ Mean I MeantSD

Figure 3. Duration of posture changes in control (concrete stalls) and experimental (matted stalls) group of gilts during a 4-hour period of observation in 4 different production cycles (seasons)

C-control group, E-experimental group, LL-lying laterally, LS-lying sternally, ST-standing, SI-sitting, $\mathrm{n}=4$ recordings per season, $\mathrm{n}=5$ gilts per group and season

aThe same postures during the same season differed statistically significantly between the two groups at the level of $P<0.001$ ${ }^{b}$ The same postures during the same season differed statistically significantly between the two groups at the level of $P<0.01$ 
The type of flooring that is inappropriate for pigs will make them feel unsafe when moving around and changing posture, thus restricting their movement and expression of natural behaviour (24). According to Anil et al. (27), the ease of lying down can be used as an indicator of sow comfort. In comparison with control gilts, experimental gilts spent significantly less time changing standing to both lying positions in all seasons (Figure 3). In contrast, the slatted-concrete floor-housed gilts had more difficulties to change these postures. The changes from standing to lying position took much longer, which could be ascribed to the slippery concrete floor as compared with the textured rubber flooring. Tuyttens et al. (13) and Elmore et al. (14) found that group-housed sows changed posture more frequently when provided with rubber mats, which is explained by the less uncomfortable and less slippery surface ensuring appropriate friction between pig claws and textured rubber mats. Yet, in the present study there were no significant betweengroup differences in the number of posture changes (Figure 2). It should be noted, however, that a higher air temperature (Figure 4) was associated with a higher rate of posture changing in both experimental and control groups of gilts (Table 1).

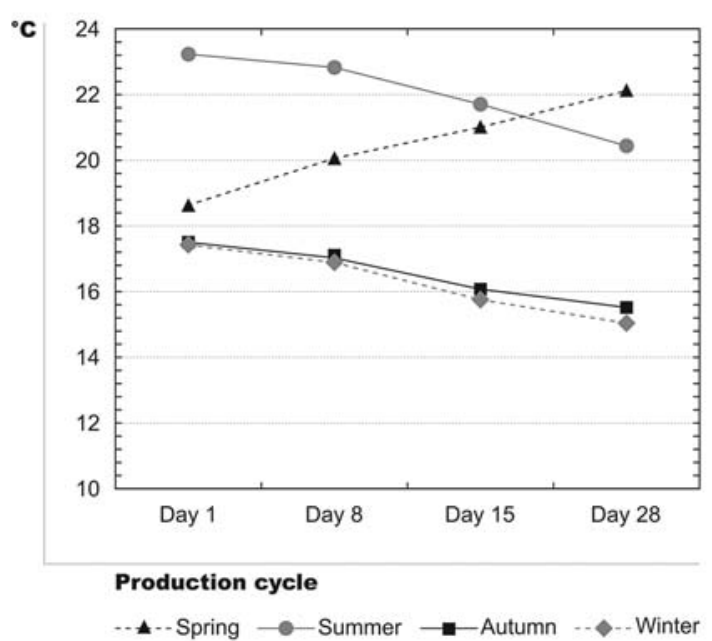

Figure 4. Air temperature in the service unit during the study period

Concrete floor slipperiness can result in animal leg and claw injuries with consequential lameness (7). In addition, the risk of injuries and lameness is even greater on slatted floor as compared with solid floor $(28,29)$. Comparing the injuries and lameness between group-housed sows on concrete slatted floor and rubber slat mats, Calderón Díaz et al. (15) found the latter to be associated with an increased risk of claw lesions, while upgrading the sow welfare by reducing the risk of lameness and limb injuries. To our knowledge, injuries and lameness in gilts housed individually in rubber floor gestation stalls have not yet been assessed, which should be taken in consideration in future studies.

\section{CONCLUSION}

Study results revealed the use of rubber mats in service unit to result in improved lying comfort in individually accommodated gilts during the cold season, suggesting that the thermal conditions in pig houses should be taken in consideration in using this type of flooring.

\section{REFERENCES}

1. Marchant-Forde, J.N. (2009). The Welfare of Pigs. Springer Science + Business Media B.V. (Eds.)

2. Aarnink, A.J.A., Schrama, J.W., Heetkamp, M.J.W., Stefanowska, J., Huynh, T.T.T. (2006). Temperature and body weight affect fouling of pig pens. J. Anim. Sci. 84, 2224-2231. http://dx.doi.org/10.2527/jas.2005-521

3. Huynh, T.T.T., Aarnink, A.J.A., Spoolder, H.A.M., Verstegen, M.W.A., Kemp, B. (2004). Effects of floor cooling during high ambient temperatures on the lying behavior and productivity of growing finishing pigs. T. ASAE 47, 1773-1782. http://dx.doi.org/10.13031/2013.17620

4. Mills, D.S., Marchant-Forde, J.N., McGreevy, P.D., Morton, D.B., Nicol, C.J., Phillips, C.J.C., Sandøe, P., Swaisgood, R.R. (2010). The encyclopedia of applied animal behaviour and welfare. Cambridge: CAB International, Cambridge University Press.

5. De Belie, N. (1997). A survey on concrete floors in pig houses and their degradation. J. Agr. Eng. Res. $66,151-156$. http://dx.doi.org/10.1006/jaer.1996.0137

6. Kymäläinen, H.R., Kuisma, R., Määttä, J., Sjöberg, A.M. (2009). Assessment of cleanness of environmental surfaces in cattle barns and piggeries. Agr. Food. Sci. 18, 268-282.

7. Telezhenko, E., Lidfors, L., Bergsten, C. (2007). Dairy cow preferences for soft or hard flooring when standing or walking. J. Dairy Sci. 90, 3716-3724. http://dx.doi.org/10.3168/jds.2006-876 PMid:17638982 
Postural behaviour in gilts housed on concrete and rubber slats

8. Færevik, G., Andersen, I.L., Boe, K.E. (2005). Preferences of sheep for different types of pen flooring. Appl. Anim. Behav. Sci. 90, 265-276. http://dx.doi.org/10.1016/j.applanim.2004.08.010

9. Gravås, L. (1979). Behavioural and physical effects of flooring on piglets and sows. Appl. Anim. Ethol. 5, 333-345.

http://dx.doi.org/10.1016/S0168-1591(99)00104-5

10. Boyle, L.A., Regan, D., Leonard, F.C., Lynch, P.B., Brophy, P. (2000). The effect of mats on the welfare of sows and piglets in the farrowing house. Anim. Welfare 9, 39-48.

11. Zurbrigg, K. (2006). Sow shoulder lesions: risk factors and treatment effects on an Ontario farm.

J. Anim. Sci. 84, 2509-2514.

http://dx.doi.org/10.2527/jas.2005-713

PMid:16908656

12. Devillers, N., Farmer, C. (2008). Effects of a new housing system and temperature on sow behaviour during lactation. Acta Agr. Scand. A-An. 58, 55-60.

13. Tuyttens, F.A.M., Wouters, F., Struelens, E., Sonck, B., Duchateau, L. (2008). Synthetic lying mats may improve lying comfort of gestating sows. Appl. Anim. Behav. Sci. 114, 76-85.

http://dx.doi.org/10.1016/j.applanim.2008.01.015

14. Elmore, M.R.P., Garner, J.P., Johnson, A.K., Richert, B.T., Pajor, E.A. (2010). A flooring comparison: the impact of rubber mats on the health, behavior, and welfare of group-housed sows at breeding. Appl. Anim. Behav. Sci. 123, 7-15. http://dx.doi.org/10.1016/j.applanim.2009.11.012

15. Calderón Díaz, J.A., Fahey, A.G., Kilbride, A.L., Green, L.E., Boyle, L.A. (2013). Longitudinal study of the effect of rubber slat mats on locomotor ability, body, limb and claw lesions, and dirtiness of group housed sows. J. Anim. Sci. 91, 3940-3954.

http://dx.doi.org/10.2527/jas.2012-5913

PMid:23881683

16. Kaiser, M., Kristensen, C.S., Bækbo, P., Alban, L. (2013). Treatment of shoulder ulcers in sows - rubber mats and zinc ointment compared to chlortetracycline spray. Acta Vet. Scand. 55, 12. http://dx.doi.org/10.1186/1751-0147-55-12 PMid:23414554; PMCid:PMC3629990

17. Calderón Díaz, J.A., Boyle, L.A. (2014). Effect of rubber slat mats on the behaviour and welfare of group housed pregnant sows. Appl. Anim. Behav. Sci. 151, 13-23.

http://dx.doi.org/10.1016/j.applanim.2013.11.016
18. Boström, M. (2011). Claw and leg lesions in preweaning piglets - a comparative study of piglets reared on structured polyurethane coating and piglets reared on concrete floors. Master's Thesis. Uppsala: Swedish University of Agricultural Sciences.

19. Gjein, H., Larssen, R.B. (1995). The effect of claw lesions and claw infections on lameness in loose housing of pregnant sows. Acta Vet Scand.36, 451-459. PMid:8669373

20. Council Directive 2008/120/EC of 18 December 2008 laying down minimum standards for the protection of pigs (Codified version). OJ L 47/5.

21. Millet, S., Moons, C.P.H., van Oeckel, M.J., Janssens, G.P.J. (2005). Welfare, performance and meat quality of fattening pigs in alternative housing and management systems: a review. J. Sci. Food Agr. 85, 709-719.

http://dx.doi.org/10.1002/jsfa.2033

22. Van de Weerd, H.A., Day, J.E.L. (2009). A review of environmental enrichment for pigs housed in intensive housing systems. Appl. Anim. Behav. Sci. 116, 1-20.

http://dx.doi.org/10.1016/j.applanim.2008.08.001

23. Ekkel, E.D., Spoolder, H.A.M., Hulsegge, I., Hopster, H. (2003). Lying characteristics as determinants for space requirements in pigs. Appl. Anim. Behav. Sci. 80, 19-30.

24. EFSA (2005). The welfare of weaners and rearing pigs: effects of different space allowances and floor types. Scientific Report, EFSA-Q-2004-077, European Food Safety Authority (EFSA) - AHAW Panel (Animal Health and Welfare), Annex to EFSA Journal 268, 1-19.

25. Ostović, M., Pavičić, Ž., Balenović, T., Ekert Kabalin, A. (2008). Utjecaj socijalnih i mikroklimatskih čimbenika na vladanje svinja tijekom hranjenja. Stočarstvo 62, 255-263.

26. Hörning, B., Raskopf, S., Simantke, C. (1992). Artgemäße Schweinehaltung - Grundlagen und Beispiele aus der Praxis (Alternative Konzepte; 78). Karlsruhe: C. F. Müller Verlag, 2. Aufl. 1993, 3. Aufl.1998, 4. Aufl. 1999, russ. Übersetzung 1997, finn.Übersetzung 1997.

27. Anil, L., Anil, S.S., Deen, J., Baidoo, S.K. (2006). Cortisol, behavioral responses, and injury scores of sows housed in gestation stalls. J. Swine Health Prod. 14, 196-201. 
28. MAFF (1981). Injuries caused by flooring: a survey in pig health scheme herds. Proc. Pig. Vet. Soc. 8, $119-125$

29. Heinonen, M., Oravainen, J., Orro, T., Seppä-Lassila, L., Ala-Kurikka, E., Virolainen, J., Tast, A., Peltoniemi, O.A.T (2006). Lameness and fertility of sows and gilts in randomly selected loosehoused herds in Finland. Vet. Rec. 159, 383-387. http://dx.doi.org/10.1136/vr.159.12.383

PMid:16980524 